\title{
Divalent cations, capacitation and the acrosome reaction in human spermatozoa*
}

\author{
Caroline E. Stock and Lynn R. Fraser $\dagger$ \\ Queen Charlotte's Maternity Hospital, Goldhawk Road, London W6 OXG, UK; and $\dagger$ Department of \\ Anatomy and Human Biology, King's College London, Strand, London WC2R 2LS, UK
}

Summary. The extracellular $\mathrm{Ca}^{2+}$ requirements for support of capacitation and the spontaneous acrosome reaction (AR) in human spermatozoa have been evaluated. Motile suspensions were prepared using a swim-up method, incubated for up to $24 \mathrm{~h}$ in media of various $\mathrm{Ca}^{2+}$ concentrations, fixed and assessed for occurrence of the AR using transmission electron microscopy. Results indicated that the AR response was significantly lower after incubation in $\mathrm{Ca}^{2+}$-deficient medium (generally $<10 \%$ reacting cells) than in $1.80 \mathrm{mM}^{-\mathrm{Ca}^{2+}}{ }^{2+}$-containing medium $(\sim 15 \%)$. In the latter the majority of cells were fully reacted, while in $\mathrm{Ca}^{2+}$-deficient conditions the majority were at intermediate stages of the AR. Subsequent experiments indicated that a maximum $\mathrm{AR}$ response required the continuous presence of millimolar $\mathrm{Ca}^{2+}$; preincubation in the presence of micromolar $\mathrm{Ca}^{2+}$ did not prepare the spermatozoa to undergo rapid $\mathrm{AR}$ upon increase of $\mathrm{Ca}^{2+}$ to millimolar concentrations, suggesting that capacitation requires relatively high concentrations of extracellular $\mathrm{Ca}^{2}{ }^{+}$. Incubation in elevated $\mathrm{Ca}^{2+}(3.60 \mathrm{~mm})$ promoted an even greater response (mean of $24-35 \%$ reacting cells compared with $12 \%$ for $1.80 \mathrm{mM}^{-\mathrm{Ca}^{2+}}$ ). The ability of the divalent cations $\mathrm{Ba}^{2+}, \mathrm{Mg}^{2+}$ and $\mathrm{Sr}^{2+}$ (each at $1.80 \mathrm{~mm}$ ) to substitute for $1.80 \mathrm{mM}-\mathrm{Ca}^{2+}$ in promoting the AR was also assessed. Of these, only $\mathrm{Sr}^{2+}$ provided a response greater than that observed in unsupplemented $\mathrm{Ca}^{2+}$-deficient medium. In $\mathrm{Sr}^{2+}$ the proportion of responding cells after $24 \mathrm{~h}(\sim 13 \%)$ was similar to that obtained in $\mathrm{Ca}^{2+}(\sim 15 \%)$, although a majority of those in $\mathrm{Sr}^{2+}$ were at intermediate stages. In $3.60 \mathrm{~mm}^{2} \mathrm{Sr}^{2+}$ the response was significantly higher than that observed in both $1.80 \mathrm{mM}^{-\mathrm{Ca}^{2}}$ and $1.80 \mathrm{mM}^{-\mathrm{Sr}^{2+}}$, but significantly lower than that in $3.60 \mathrm{~mm}^{-\mathrm{Ca}^{2+}}$. Under all conditions motility was maintained at $>90 \%$ for $24 \mathrm{~h}$. The introduction of the $\mathrm{Ca}^{2+}$ ionophore ionomycin, in the presence of $1.80 \mathrm{mM}^{-\mathrm{Ca}^{2}}$, induced the AR in a concentrationdependent but preincubation time-independent manner, with the maximum response of $\sim 60 \%$ being obtained with $30 \mu \mathrm{M}$-ionomycin. Finally, incubation in the presence of $1.80 \mathrm{mM}^{-\mathrm{Ca}^{2}}$ and verapamil, generally considered to be a calcium channel antagonist, resulted in a concentration- and incubation time-dependent increase in the AR, the maximum response in all groups being observed only after $24 \mathrm{~h}$ incubation. Recent evidence from other species suggests that this may represent an agonistic interaction with calcium channels. We conclude that optimal conditions for capacitation and the $A R$ in human spermatozoa require extracellular $\mathrm{Ca}^{2+}$ at $\geq 1.80 \mathrm{mM}$. An influx of $\mathrm{Ca}^{2+}$ is associated with $\mathrm{AR}$ initiation, as indicated by the ionomycin-induced response, and calcium channels may play a role in the entry of $\mathrm{Ca}^{2+}$ into capacitated cells just before the AR. While $\mathrm{Sr}^{2+}$ and $\mathrm{Ca}^{2+}$ both appear able to support capacitation and initiation of the AR in human spermatozoa, $\mathrm{Sr}^{2+}$ is less effective in promoting completion of the

\footnotetext{
*Reprint requests to Dr Lynn R. Fraser.
} 
AR. This may have relevance to other reports that zona binding and gamete fusion in the human are lower in the presence of $\mathrm{Sr}^{2+}$ than $\mathrm{Ca}^{2+}$.

Keywords: calcium; acrosome reaction; capacitation; ionomycin; verapamil; strontium; man

\section{Introduction}

Extracellular calcium ions are obligatory for successful fertilization in invertebrates (Loeb, 1915) and mammals (mouse: Iwamatsu \& Chang, 1971). In all species examined, an influx of $\mathrm{Ca}^{2+}$ is required to trigger the acrosome reaction (AR) which results in release of lytic enzymes and membrane alterations required for sperm-egg interaction. In mammalian spermatozoa, with a requirement for capacitation which prepares them for the acrosome reaction, $\mathrm{Ca}^{2+}$ may play a role during both these initial stages as well as the terminal ones associated with the acrosome reaction. Current evidence suggests this to be true for hamster (Yanagimachi, 1982) and mouse (Fraser, 1982, 1987b) spermatozoa, although guinea-pig spermatozoa appear to undergo capacitation in the absence of added $\mathrm{Ca}^{2+}$ : if incubated for a sufficient time in $\mathrm{Ca}^{2+}$-deficient medium, the introduction of millimolar concentrations of $\mathrm{Ca}^{2+}$ triggers a rapid AR response (Yanagimachi \& Usui, 1974). Similar treatment of hamster (Yanagimachi, 1982) and mouse (Fraser, 1982) spermatozoa, using incubation times which support complete capacitation in the presence of extracellular $\mathrm{Ca}^{2+}$, does not evoke an immediate AR in the majority of cells and does not promote immediate expression of optimal fertilizing ability; these cells therefore appear to be only partly capacitated. For mouse spermatozoa, incubation for a further $60 \mathrm{~min}$ after addition of millimolar $\mathrm{Ca}^{2+}$ leads to complete capacitation: such cells are able to fertilize rapidly a majority of eggs (Fraser, 1987b). Furthermore, the minimum $\mathrm{Ca}^{2+}$ concentrations required to support mouse sperm capacitation per se and optimal fertilization differ markedly, being $90 \mu \mathrm{M}$ and $1.80 \mathrm{mM}$, respectively (Fraser, 1987b).

Considerable interest is now being focussed on human spermatozoa and their specific requirements for capacitation, the AR and fertilization. We have recently described the time-dependent pattern of spontaneous AR in human spermatozoa, from men of proven fertility, during incubation under conditions which support fertilization in vitro (Stock \& Fraser, 1987). In the present study we have compared the incidence of spontaneous AR in suspensions of human spermatozoa incubated in the presence or absence of added $\mathrm{Ca}^{2+}$. We have also examined the response to addition of ionomycin, a divalent cation ionophore which promotes the entry of $\mathrm{Ca}^{2+}$, and verapamil, a calcium channel antagonist (Triggle \& Janis, 1987).

We have also examined the possibility that divalent cations other than $\mathrm{Ca}^{2+}$ might be able to support capacitation and/or the $\mathrm{AR}$. In other studies, $\mathrm{Sr}^{2+}$ has proved to be the most effective ion to replace $\mathrm{Ca}^{2+}$, being able to support both the AR and hyperactivated motility in guinea-pig spermatozoa (Yanagimachi \& Usui, 1974), sperm-egg fusion in the hamster (Yanagimachi, 1978), and capacitation, AR, hyperactivated motility, zona penetration and sperm-egg fusion in the mouse (Fraser, 1987c). There have also been reports that human spermatozoa preincubated in $\mathrm{Sr}^{2+}$ were more successful in fertilizing zona-free hamster eggs in the presence of $\mathrm{Ca}^{2+}$ than control cells incubated continuously in $\mathrm{Ca}^{2+}$ (Mortimer, 1986; Mortimer et al., 1986). These latter results suggested that perhaps $\mathrm{Sr}^{2+}$-treated spermatozoa were able to undergo capacitation but not the AR. In the present study we have evaluated the AR response in human spermatozoa incubated continuously in $\mathrm{Sr}^{2+}, \mathrm{Ba}^{2+}$ or $\mathrm{Mg}^{2+}$ and compared this with counterparts incubated in $\mathrm{Ca}^{2+}$. Because of the existing evidence, we have focussed primarily on $\mathrm{Sr}^{2+}$.

\section{Materials and Methods}

Media. The standard medium was Earle's medium, with added gentamicin, which contained $1 \cdot 80 \mathrm{mM}^{-\mathrm{CaCl}} \mathrm{2} \cdot \mathrm{Modifi}-$ cations involved alterations in the concentration of $\mathrm{Ca}^{2+}$ : $\mathrm{Ca}^{2+}$-deficient (no added $\mathrm{CaCl}_{2}$ ), low $\mathrm{Ca}^{2+}$ 
$(0.45-0.9 \mathrm{~mm})$ and elevated $\mathrm{Ca}^{2+}(3.60 \mathrm{~mm})$. Where necessary, extra $\mathrm{NaCl}$ was added to maintain osmolality at 275-285 mosmol (measured on an osmometer). To study other divalent cations, $1.80 \mathrm{mM}-\mathrm{BaCl}_{2},-\mathrm{MgCl}_{2}$ or $-\mathrm{SrCl}_{2}$ was added to $\mathrm{Ca}^{2+}$-deficient medium; elevated $\mathrm{Sr}^{2+}$ at $3.60 \mathrm{mM}(\times 2)$ was also evaluated. In some experiments initial incubation in $\mathrm{Ca}^{2+}$-deficient (with or without other divalent cations) or low $\mathrm{Ca}^{2+}$-media was followed by an increase in $\mathrm{Ca}^{2+}$ concentration to $1.80 \mathrm{mM}$; appropriate concentrated $\mathrm{CaCl}_{2}$ stocks were used to accomplish this. All media contained Fraction V human serum albumin (hSA; Sigma, Poole, Dorset, UK) at $5 \mathrm{mg} / \mathrm{ml}$.

Stocks of the ionophore ionomycin (Calbiochem, Cambridge BioScience, Cambridge, UK) were prepared in DMSO; the final concentration of DMSO in sperm suspensions was $0.5 \%$ for all concentrations of ionomycin examined. Verapamil (Sigma) stocks were prepared in $0.9 \% \mathrm{NaCl}$; the final dilution factor for each was $\times 100$.

Sperm preparation. Semen was obtained from fertile donors and from individuals undergoing assessment in the Seminology Laboratory, Chelsea Hospital for Women. Semen $(0.5 \mathrm{ml})$ was gently pipetted under $1 \mathrm{ml}$ of the appropriate medium in 14-ml plastic tubes (Falcon Plastics, Becton Dickinson UK Ltd, Cowley, Oxford, UK) and allowed to swim up for $1-1.5 \mathrm{~h}$ at $37^{\circ} \mathrm{C}$. Motile cells were carefully aspirated from the upper interface with a Pasteur pipette. A small drop on a microscope slide was assessed for proportion of spermatozoa exhibiting progressive motility; this was $\geq 95 \%$. Sperm concentration was determined with a haemocytometer and adjusted to $5 \times 10^{6}$ cells $/ \mathrm{ml}$. Suspensions were gassed with $5 \% \mathrm{CO}_{2}-5 \% \mathrm{O}_{2}-90 \% \mathrm{~N}_{2}$ and incubated at $37^{\circ} \mathrm{C}$.

Series I. Spermatozoa were allowed to swim up into $\mathrm{Ca}^{2+}$-containing $(+\mathrm{Ca})$ and $\mathrm{Ca}^{2+}$-deficient $(-\mathrm{Ca})$ media. Suspensions were incubated for a total of $24 \mathrm{~h}$, with aliquants being removed at $6 \mathrm{~h}$ and $24 \mathrm{~h}$, fixed, processed for transmission electron microscopy (details below) and assessed. Twenty samples were examined $(n=20)$.

Series II. Motile suspensions $(n=8)$ were prepared in -Ca and + Ca media and incubated as for Series I. At $6 \mathrm{~h}$, an aliquant of the $-\mathrm{Ca}$ suspension was removed and $\mathrm{CaCl}_{2}$ stock added to raise the $\mathrm{Ca}^{2+}$ concentration to $1.80 \mathrm{~mm}$ ( $-\mathrm{Ca} \rightarrow+\mathrm{Ca}$ group). After $15 \mathrm{~min}$, this sample plus an aliquant from both the $+\mathrm{Ca}$ and $-\mathrm{Ca}$ suspensions were fixed and assessed. The procedure was repeated at $24 \mathrm{~h}$.

Series III. Motile suspensions $(n=3)$ were prepared in $-\mathrm{Ca}$, low $\mathrm{Ca}\left(0 \cdot 45-0.9 \mathrm{~mm}-\mathrm{CaCl}_{2}\right)$ and $+\mathrm{Ca}$ media and incubated. At $6 \mathrm{~h}$, an aliquant of the low Ca suspension was removed and the $\mathrm{Ca}^{2+}$ concentration raised to $1.80 \mathrm{~mm}$. After $15 \mathrm{~min}$ this sample plus one from each of the other suspensions were fixed. This resulted in 4 treatment groups ( $-\mathrm{Ca}$, low $\mathrm{Ca}$, low $\mathrm{Ca} \rightarrow+\mathrm{Ca}$ and $+\mathrm{Ca}$ ). The procedure was repeated at $24 \mathrm{~h}$.

Series $I V$. Motile suspensions were prepared in standard medium $\left(1.80 \mathrm{~mm}-\mathrm{CaCl}_{2} ;+\mathrm{Ca}\right)$ and medium with elevated $\mathrm{Ca}^{2+}\left(3.60 \mathrm{~mm}-\mathrm{CaCl}_{2} ; \times 2 \mathrm{Ca}\right)$ and incubated. Aliquants were removed from both suspensions at $6 \mathrm{~h}$, if sufficient suspension was available, and at $24 \mathrm{~h}$ and fixed ( $n=3$ for $6 \mathrm{~h} ; n=6$ for $24 \mathrm{~h}$ ).

Series $V$. Motile suspensions $(n=6)$ were prepared in standard medium. Aliquants were removed at 0,3 and $6 \mathrm{~h}$ and received either DMSO $(0.5 \%$ final concentration) or ionomycin (final concentration of 3,10 and $30 \mu \mathrm{M}$ in $0.5 \%$ DMSO). After $15 \mathrm{~min}$, motility was assessed and the suspensions were fixed. A drug-free control was also included at each time point.

Series VI. Motile suspensions $(n=4)$ were prepared in standard Earle's medium, diluted to $5 \times 10^{6} \mathrm{cells} / \mathrm{ml}$ and 4 aliquants prepared. One of these served as the drug-free control; verapamil stock solutions were added to the remaining aliquants to give final concentrations of 25,50 and $100 \mu \mathrm{M}$-verapamil. Samples were removed from each at 3,6 and $24 \mathrm{~h}$, assessed for motility and fixed.

Series VII. Motile suspensions $(n=5)$ were prepared in the following media: $-\mathrm{Ca},+\mathrm{Ca},+\mathrm{Ba}(1 \cdot 80 \mathrm{~mm}-\mathrm{BaCl})$ and $+\mathrm{Mg}\left(1.80 \mathrm{~mm}-\mathrm{MgCl}_{2}\right)$. After incubation for $24 \mathrm{~h}$, aliquants were removed from the $+\mathrm{Ba}$ and $+\mathrm{Mg}$ suspensions and $\mathrm{Ca}^{2+}$ stock solution was added to give a final concentration of $1.80 \mathrm{~mm}-\mathrm{Ca}^{2+}$. After $15 \mathrm{~min}$, all 6 samples $(-\mathrm{Ca}$, $+\mathrm{Ba},+\mathrm{Ba} \rightarrow+\mathrm{Ca},+\mathrm{Mg},+\mathrm{Mg} \rightarrow+\mathrm{Ca},+\mathrm{Ca})$ were fixed and assessed.

Series VIII. Motile suspensions $(n=8)$ were prepared in the following media: $-\mathrm{Ca}$, $+\mathrm{Ca}$ and $+\mathrm{Sr}(1 \cdot 80 \mathrm{~mm}-$ $\mathrm{SrCl}_{2}$ ). These were incubated for a total of $24 \mathrm{~h}$. At $6 \mathrm{~h}$, an aliquant of the $+\mathrm{Sr}$ suspension was removed, centrifuged at $600 \mathrm{~g}$ for $5 \mathrm{~min}$ and resuspended in $+\mathrm{Ca}$ medium. After incubation for $15 \mathrm{~min}$, this and aliquants from the $-\mathrm{Ca}$, $+\mathrm{Ca}$ and $+\mathrm{Sr}$ samples were fixed. The 4 treatments were therefore $-\mathrm{Ca},+\mathrm{Ca},+\mathrm{Sr}$ and $+\mathrm{Sr} \rightarrow+\mathrm{Ca}$. $\mathrm{The}$ procedure was repeated at $24 \mathrm{~h}$.

Series IX. Motile suspensions $(n=9)$ were prepared in the following media: $-\mathrm{Ca},+\mathrm{Ca},+\mathrm{Sr},+2 \times \mathrm{Ca}$ $\left(3.60 \mathrm{mM}-\mathrm{CaCl}_{2}\right)$ and $+2 \times \mathrm{Sr}\left(3.60 \mathrm{~mm}-\mathrm{SrCl}_{2}\right)$. After incubation for $24 \mathrm{~h}$, aliquants from the $+\mathrm{Sr}$ and $+2 \times \mathrm{Sr}$ suspensions were centrifuged as in Series VIII and resuspended in $+\mathrm{Ca}$ medjum for $15 \mathrm{~min}$. These and the remaining samples were fixed, giving a total of 7 treatment groups: $-\mathrm{Ca},+\mathrm{Ca},+\mathrm{Sr},+\mathrm{Sr} \rightarrow+\mathrm{Ca},+2 \times \mathrm{Ca},+2 \times \mathrm{Sr}$ and $+2 \times \mathrm{Sr} \rightarrow+\mathrm{Ca}$. With this increase in treatments, some samples had insufficient spermatozoa to assess all 7 conditions. The minimum number of replicates for any one set of conditions was 6 .

Processing and assessment. All samples were fixed in $3 \%$ glutaraldehyde in $0 \cdot 1 \mathrm{M}$-cacodylate buffer, $\mathrm{pH} 7 \cdot 2$, for $45 \mathrm{~min}$ at room temperature. They were then centrifuged at $600 \mathrm{~g}$ for $5 \mathrm{~min}$ and the pellet was resuspended in fresh $0.1 \mathrm{M}$-cacodylate buffer. After $24 \mathrm{~h}$ samples were post-fixed in $1 \%$ osmium tetroxide, washed in $50 \%$ alcohol, 'blocked up' in molten agar (Ryder \& McKenzie, 1981), dehydrated in graded alcohols and embedded in araldite resin. Ultrathin sections were stained with uranyl acetate and lead citrate and examined with either a Philips $301 \mathrm{G}$ or Hitachi HU12A electron microscope. 
A minimum of 200 sperm heads was assessed in each sample. Each cell was classified into one of the 6 stages of the AR which we have previously described (Stock \& Fraser, 1987; Stock et al., 1989): Stage I cells are acrosome-intact; Stages 2-4 are at intermediate stages at which initiation of the AR can be seen (swelling of the acrosomal cap, formation of intraacrosomal vesicles from the outer acrosomal membrane, loss of acrosomal matrix despite retention of plasma and outer acrosomal membranes); Stages 5 and 6 are acrosome-reacted with exposed inner acrosomal membrane except in the equatorial segment (vesicles may still be associated with the sperm head). Only morphologically normal heads were counted.

Data were analysed using Cochran's modification of the $2 \times 2$ contingency tables (Snedecor \& Cochran, 1967). This allows for comparison within and between replicates.

\section{Results}

\section{Series I: is extracellular $\mathrm{Ca}^{2+}$ required for the $\mathrm{AR}$ ?}

The total mean proportion of spermatozoa which had initiated (Stages 2-4) or completed (Stages $5 \& 6$ ) the AR was significantly lower in the $-\mathrm{Ca}$ suspensions than in their $+\mathrm{Ca}$ counterparts at $6 \mathrm{~h}(5.8 \%$ vs $10.0 \%$, respectively; $P<0.01)$ and $24 \mathrm{~h}(8.4 \%$ vs $14.7 \%$, respectively; $P<0.01)$. Most of the cells in -Ca medium were at intermediate stages rather than having completed the reaction (Fig. 1). In the $+\mathrm{Ca}$ suspensions, the opposite pattern was observed and at $24 \mathrm{~h}$ about two-thirds of all positive cells were fully reacted. Motility was maintained at a mean of $\geq 90 \%$ in both treatment groups. From this we conclude that extracellular $\mathrm{Ca}^{2+}$ is required for the $\mathrm{AR}$ in human spermatozoa.
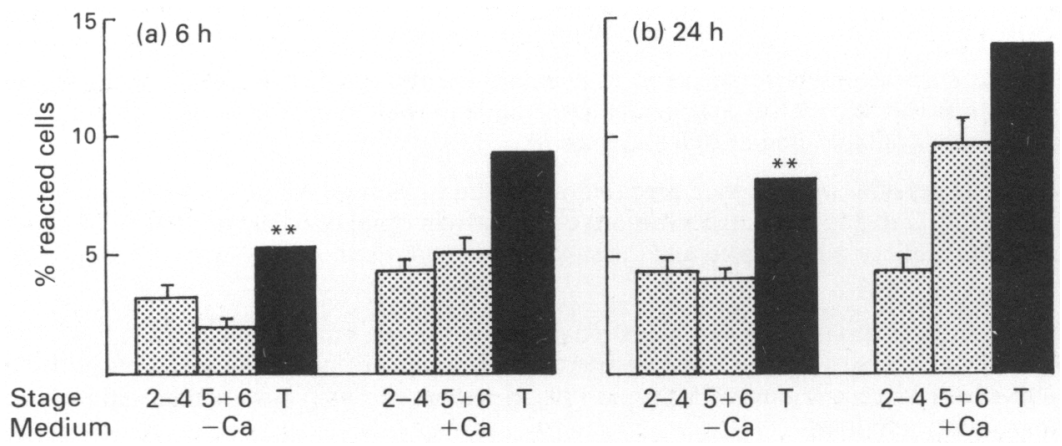

Fig. 1. AR response in human sperm suspensions incubated for (a) $6 \mathrm{~h}$ and (b) $24 \mathrm{~h}$ in calciumdeficient medium ( $-\mathrm{Ca}$ ) and calcium-containing medium $\left(+\mathrm{Ca} ; 1.80 \mathrm{~mm}-\mathrm{Ca}^{2+}\right.$ ). The stippled bars represent the proportion of cells at intermediate Stages $2-4$ and reacted Stages $5+6$. The solid bars ( $T$ ) represent the total mean reacted cells (Stages $2-6$ ). Values are mean $\% \pm$ s.e.m. $(n=20){ }^{* *} P<0.01$ compared with + Ca controls.

\section{Series II: will $\mathrm{Ca}^{2+}$ added at the end of incubation trigger the AR?}

In this series responses in 3 groups were compared: $-\mathrm{Ca},-\mathrm{Ca} \rightarrow+\mathrm{Ca}$ and $+\mathrm{Ca}$. Results (Fig. $2)$ indicate that the mean proportion of cells at Stages $2-6$ was significantly lower $(P<0.05)$ in the $-\mathrm{Ca}$ and $-\mathrm{Ca} \rightarrow+\mathrm{Ca}$ suspensions when compared with their $+\mathrm{Ca}$ counterparts at $6 \mathrm{~h}(-\mathrm{Ca}$, $5 \cdot 0 \% ;-\mathrm{Ca} \rightarrow+\mathrm{Ca}, 4 \cdot 9 \% ;+\mathrm{Ca}, 9 \cdot 4 \%)$ and $24 \mathrm{~h}(-\mathrm{Ca}, 8 \cdot 3 \% ;-\mathrm{Ca} \rightarrow+\mathrm{Ca}, 7 \cdot 9 \% ;+\mathrm{Ca}, 13 \cdot 2 \%)$. There were no detectable differences between $-\mathrm{Ca}$ and $-\mathrm{Ca} \rightarrow+\mathrm{Ca}$ suspensions. In both groups, as in $-\mathrm{Ca}$ in Series I, most cells were at intermediate stages. Motility at $\geq 95 \%$ was maintained in all groups. We conclude that extracellular $\mathrm{Ca}^{2+}$ cannot trigger the AR in human spermatozoa incubated for up to $24 \mathrm{~h}$ in $\mathrm{Ca}^{2+}$-deficient medium; this would suggest that extracellular $\mathrm{Ca}^{2+}$ needs to be present during capacitation. 


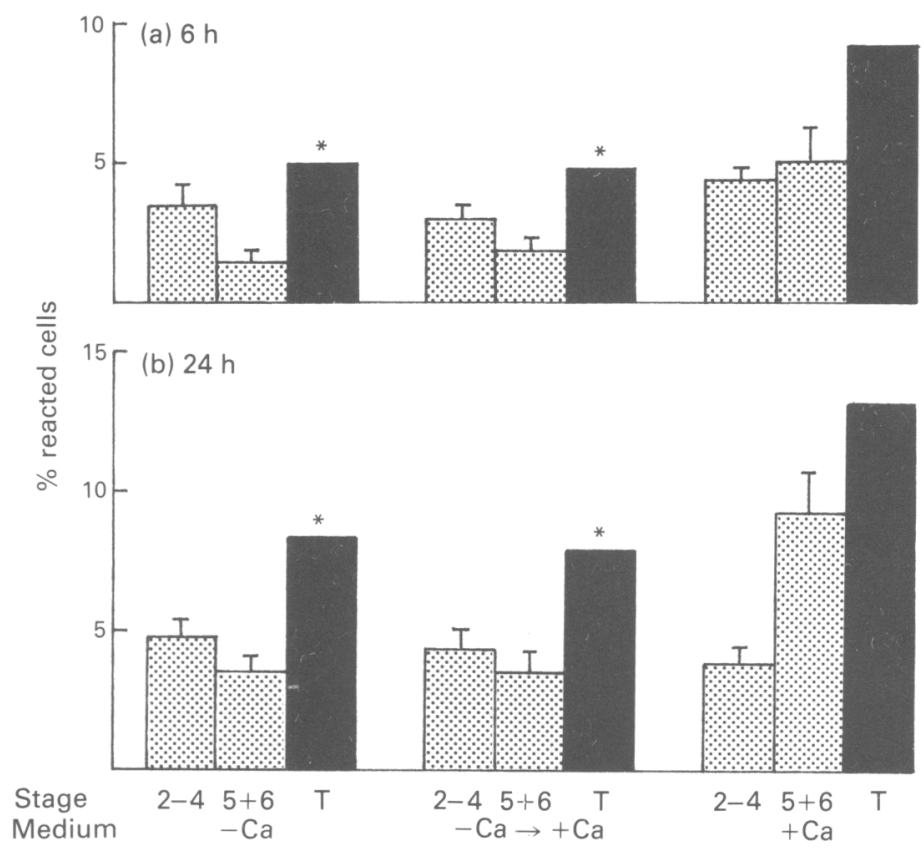

Fig. 2. AR response in human sperm suspensions incubated for (a) $6 \mathrm{~h}$ and (b) $24 \mathrm{~h}$ in calciumdeficient medium $(-\mathrm{Ca})$, calcium-containing medium $(+\mathrm{Ca})$ and calcium-deficient medium with $1.80 \mathrm{~mm}_{-} \mathrm{Ca}^{2+}$ being added for the final $15 \mathrm{~min}(-\mathrm{Ca} \rightarrow+\mathrm{Ca})$. Values are mean $\% \pm$ s.e.m. $(n=8) .{ }^{*} P<0.05$ compared with + Ca controls.

Series III: will low $\mathrm{Ca}^{2+}$ concentrations present during incubation permit terminal addition of high $\mathrm{Ca}^{2+}$ to trigger the AR?

Four treatment groups were compared: $-\mathrm{Ca}$, low $\mathrm{Ca}$, low $\mathrm{Ca} \rightarrow+\mathrm{Ca}$ and $+\mathrm{Ca}$. In one replicate $0.45 \mathrm{~mm}-\mathrm{CaCl}_{2}$ was used for low $\mathrm{Ca}$ and in two, $0.9 \mathrm{mM}-\mathrm{CaCl}_{2}$ was used. Responses were similar and therefore have been combined. As can be seen in Fig. 3, responses in $+\mathrm{Ca}$ were higher than those in the other 3 groups at $6 \mathrm{~h}(-\mathrm{Ca}, 5 \cdot 3 \%$; low $\mathrm{Ca}, 4 \cdot 3 \% ; \mathrm{low} \rightarrow+\mathrm{Ca}, 5 \cdot 6 \% ;+\mathrm{Ca}, 9 \cdot 6 \%)$ and $24 \mathrm{~h}(-\mathrm{Ca}, 8 \cdot 0 \%$; low $\mathrm{Ca}, 9 \cdot 4 \%$; low $\mathrm{Ca} \rightarrow+\mathrm{Ca}, 9 \cdot 6 \%$; $+\mathrm{Ca}, 12 \cdot 7 \%)$. Again the patterns of response were consistent with those observed in the earlier series: in $+\mathrm{Ca}$ suspensions, the majority of cells were fully reacted while in the 3 with reduced $\mathrm{Ca}^{2+}$ present during initial incubation the reverse was true. Because the responses were consistent in the 3 replicates, further ones were not carried out. Motility was maintained at $\geq 95 \%$ in all groups. We suggest that human spermatozoa require continuous exposure to high (millimolar range) $\mathrm{Ca}^{2+}$ concentrations in order to complete capacitation and to undergo the AR.

\section{Series IV: what is the effect of elevated extracellular $\mathrm{Ca}^{2+}$ on the $\mathrm{AR}$ response?}

The continuous presence of $2 \times \mathrm{Ca}(3.60 \mathrm{~mm})$ resulted in a significantly higher $(P<0.001)$ incidence of AR (34.7\%) at $24 \mathrm{~h}$ in comparison with the standard + Ca (11.9\%) (Fig. 4). One of the $2 \times \mathrm{Ca} 24 \mathrm{~h}$ group exhibited a massive proportion of reacted cells $(91 \%)$ with most at Stages 5 and 6. Despite the unusually high value, the mean responses in this $2 \times \mathrm{Ca}$ sample at $6 \mathrm{~h}$ and in both the 6 and $24 \mathrm{~h}+$ Ca samples were unremarkable and we have no firm basis for rejecting this value. If it is ignored, however, the mean response is still elevated $(24.2 \% ; P<0.01)$. In all samples motility was maintained at $\geq 95 \%$ throughout the 24 -h incubation period. We conclude that elevated extracellular $\mathrm{Ca}^{2+}$ concentrations stimulate the AR. 


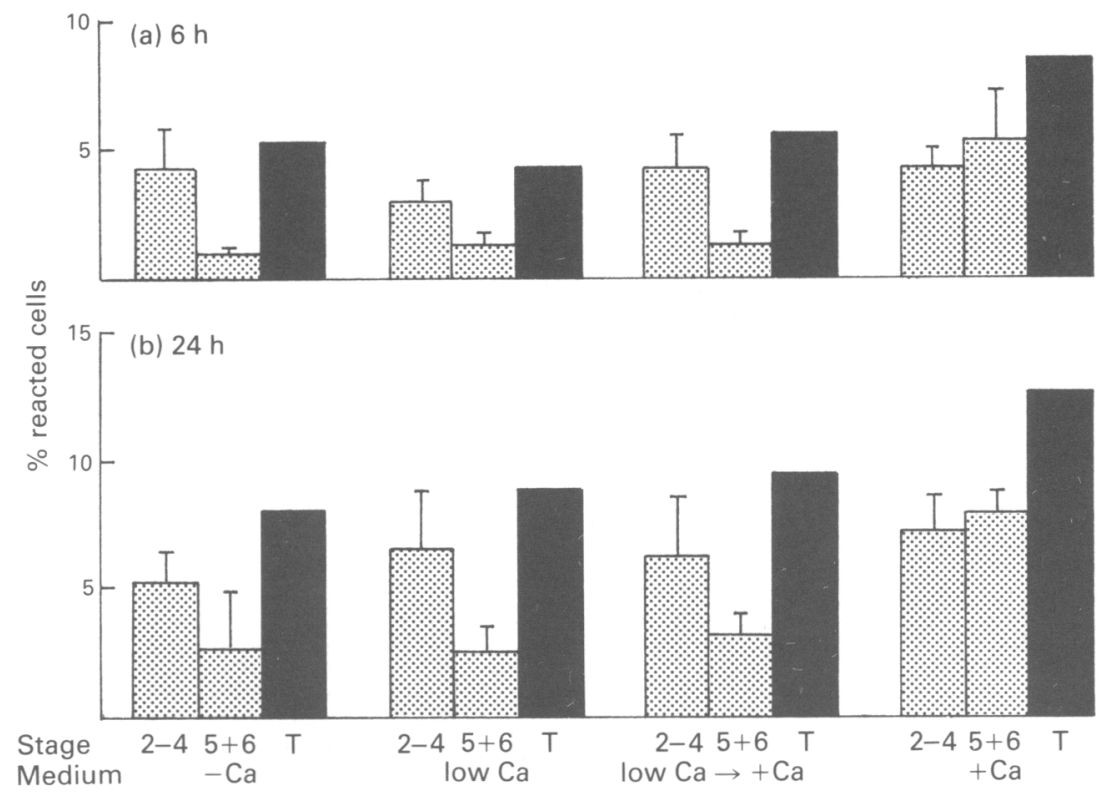

Fig. 3. AR response in human sperm suspensions incubated for (a) $6 \mathrm{~h}$ and (b) $24 \mathrm{~h}$ in calciumdeficient medium $(-\mathrm{Ca})$, calcium-containing medium $(+\mathrm{Ca})$, low calcium medium (low $\mathrm{Ca}$; $0.45-0.90 \mathrm{mM}^{-\mathrm{Ca}^{2}}$ ) and low calcium medium with calcium raised to $1.80 \mathrm{~mm}$ for the final 15 min (low $\mathrm{Ca} \rightarrow+\mathrm{Ca})$. Values are mean $\% \pm$ s.e.m. $(n=3)$.
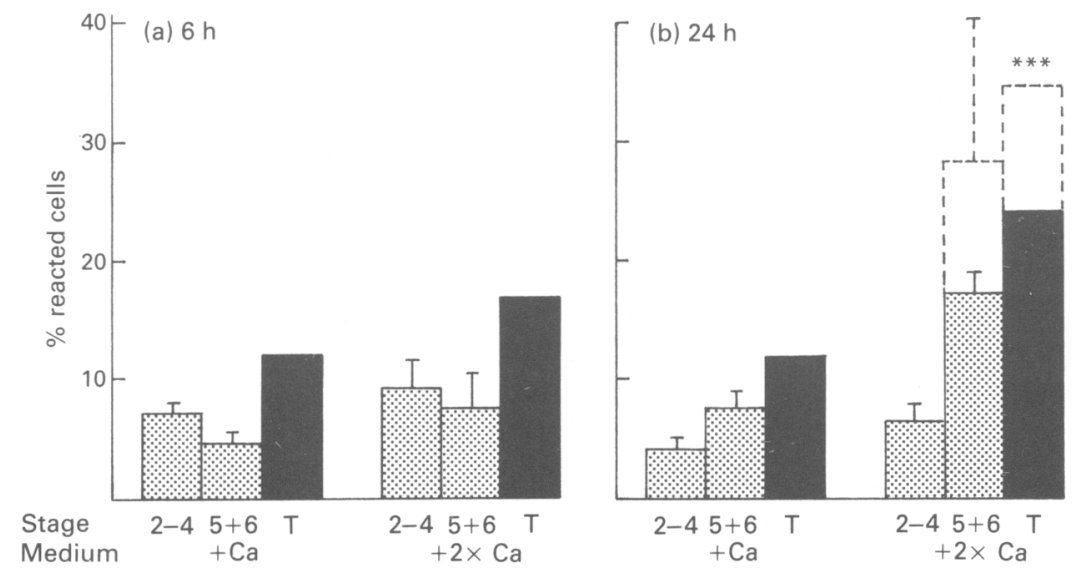

Fig. 4. AR response in human sperm suspensions incubated for (a) $6 \mathrm{~h}$ and (b) $24 \mathrm{~h}$ in standard calcium-containing medium $\left(+\mathrm{Ca} ; 1.80 \mathrm{~mm}-\mathrm{Ca}^{2+}\right)$ and elevated calcium medium $(+2 \times \mathrm{Ca}$; $3.60 \mathrm{mM}-\mathrm{Ca}^{2+}$ ). Values are mean $\% \pm$ s.e.m. The broken lines indicate the mean value, including the unusually high response in one aliquant; the solid bars indicate the mean excluding that sample (total $n=3$ for $3 \mathrm{~h}$ and 6 for $24 \mathrm{~h}$ ). ${ }^{* * *} P<0.001$ compared with $+\mathrm{Ca}$ controls for all samples $(* * P<0.01$ excluding the high response).

Series V: what is the effect of ionomycin on the $A R$ in suspensions incubated in $\mathrm{Ca}^{2+}$-containing medium?

A significant increase $(P<0.05-P<0.001$, depending on treatment) in the incidence of AR was observed in all ionomycin-treated suspensions, compared with the drug-free controls (Fig. 5). 

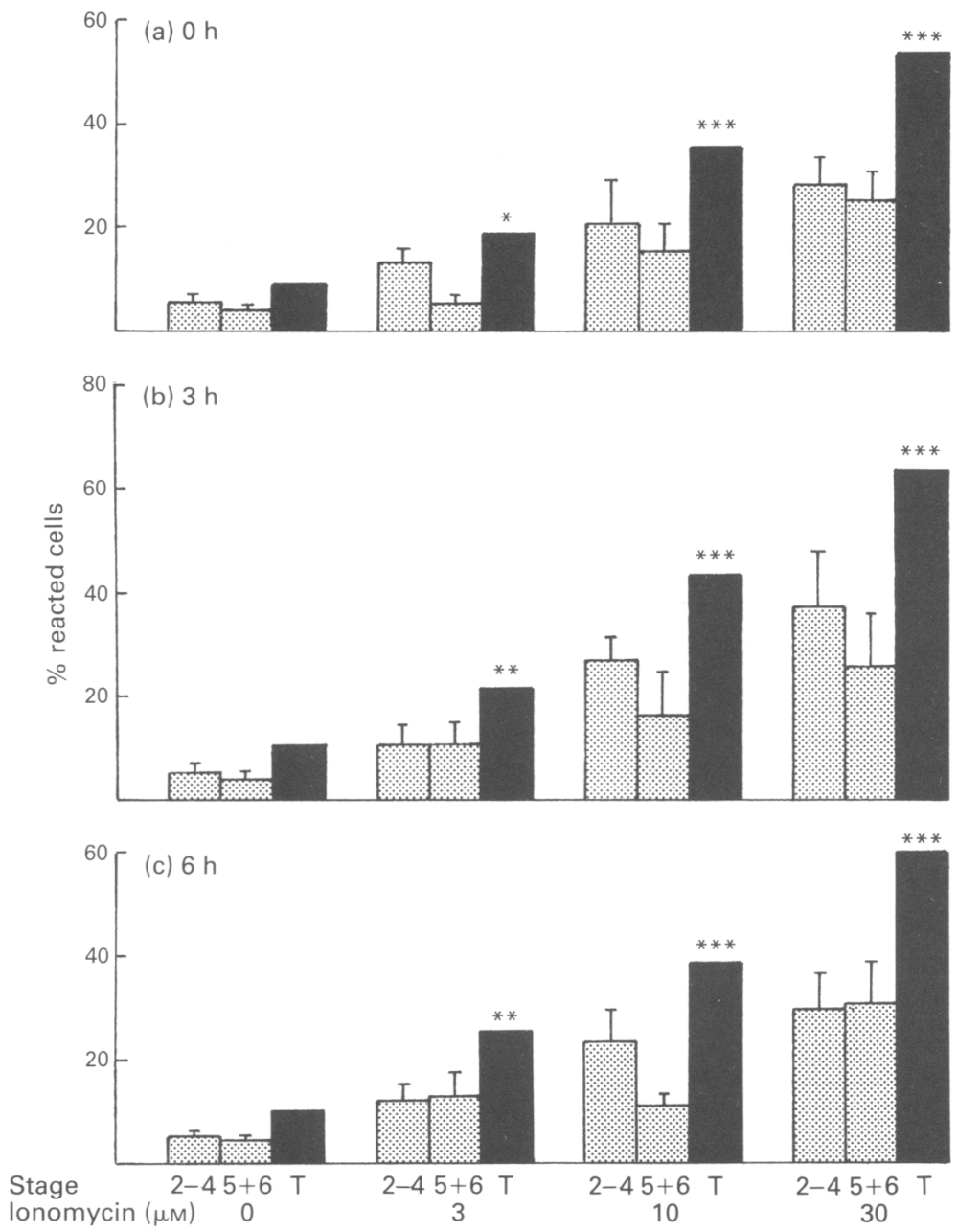

Fig. 5. AR response in human sperm suspensions preincubated for (a) $0 \mathrm{~h}$, (b) $3 \mathrm{~h}$ and (c) $6 \mathrm{~h}$ in calcium-containing medium $\left(1.80 \mathrm{mM}-\mathrm{Ca}^{2+}\right)$ and then incubated in ionomycin $(0-30 \mu \mathrm{M})$ for 15 min. Values are mean $\% \pm$ s.e.m. $(n=6) .{ }^{*} P<0.05,{ }^{* *} P<0.01,{ }^{* * *} P<0.001$ compared with appropriate drug-free controls.

The magnitude of the response was concentration-dependent, the greatest response being elicited by $30 \mu \mathrm{m}$-ionophore, but the responses were similar at all 3 time points for each drug concentration evaluated. The total mean proportions of responding cells at 0,3 and $6 \mathrm{~h}$ were: $3 \mu \mathrm{M}-18 \cdot 8 \%$, $21 \cdot 8 \%, 25 \cdot 6 \% ; 10 \mu \mathrm{M}-35 \cdot 7 \%, 43 \cdot 6 \%, 34.8 \% ; 30 \mu \mathrm{M}-53 \cdot 8 \%, 63 \cdot 0 \%, 59 \cdot 8 \%$. Although there was an increase in the mean $\%$ reacted cells from $0 \mathrm{~h}$ to $3 \mathrm{~h}$ in all groups, this was only significant $(P<0.05)$ in $30 \mu \mathrm{M}$-ionomycin. Since an increase was not observed in all suspensions in any of the treatment groups, a much larger sample size would be needed to determine whether the increase was of biological relevance. In general, half or more of the responding cells were at intermediate stages (2-4), indicating that ionomycin did not necessarily induce a completed AR within the $15 \mathrm{~min}$ allowed for response. DMSO itself had no detectable effect on the response (data not presented). Motility at $>95 \%$ was maintained in the ionomycin-free samples throughout the 6-h incubation period. No obvious effect was observed with $3 \mu \mathrm{M}$-ionomycin and values of $\geq 90 \%$ were maintained with $10 \mu \mathrm{M}$. The highest concentration, $30 \mu \mathrm{M}$, caused a marked decline during the 


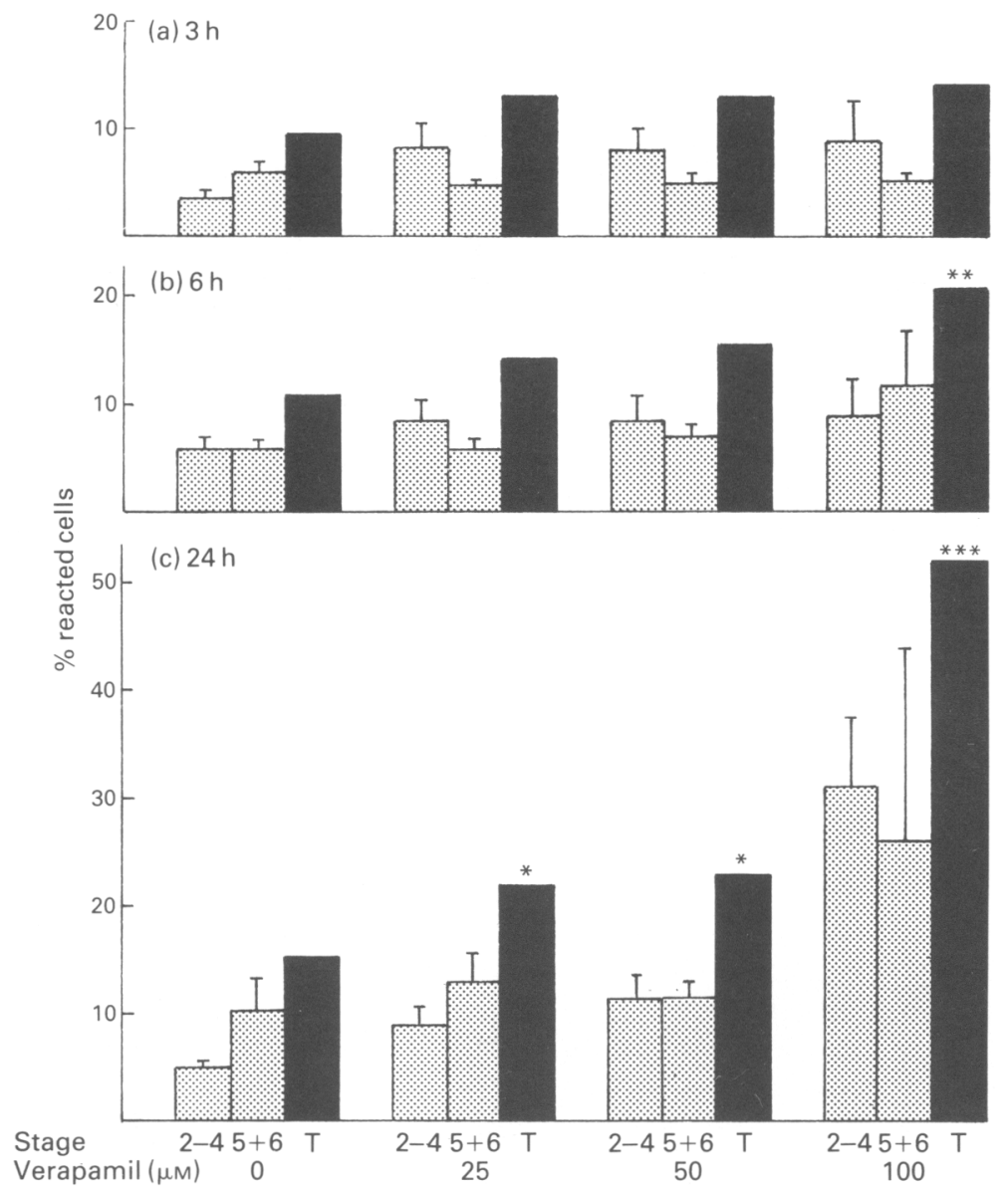

Fig. 6. AR response in human sperm suspensions incubated for (a) $3 \mathrm{~h}$, (b) $6 \mathrm{~h}$ and (c) $24 \mathrm{~h}$ in increasing concentrations of verapamil $(0-100 \mu \mathrm{M})$. Values are mean $\% \pm$ s.e.m. $(n=4)$. ${ }^{*} P<0.05,{ }^{* *} P<0.01,{ }^{* * *} P<0.001$ compared with appropriate drug-free controls.

$15-\mathrm{min}$ treatment period to values of $0-70 \%$. We conclude that ionomycin induces an influx of extracellular $\mathrm{Ca}^{2+}$ and thereby triggers the AR.

\section{Series VI: what effect does verapamil, a calcium channel antagonist, have on the AR?}

The effects of verapamil treatment were dependent on both the drug concentration and the length of incubation (Fig. 6). After 3 h no significant differences were detected among the 4 treatment groups, with the mean total $\%$ of reacting/reacted cells ranging from $10 \cdot 3$ to $14 \cdot 1 \%$, but after $6 \mathrm{~h}$ a significantly higher AR response (mean of $20.6 \% ; P<0.01$ ) was observed in the $100 \mu \mathrm{M}-$ verapamil group than in the others $(12 \cdot 3-15 \cdot 5 \%)$. After $24 \mathrm{~h}$, a significantly elevated response was detected in all 3 verapamil-treated groups: $25 \mu \mathrm{M}(22.0 \%)$ and $50 \mu \mathrm{M}(22.8 \%), P<0.05 ; 100 \mu \mathrm{M}$ $(57.0 \%), P<0.001$, when compared with drug-free controls $(15.3 \%)$. Motility was maintained at $\geq 90 \%$ with the exception of one suspension after $24 \mathrm{~h}$ in $100 \mu \mathrm{M}$-verapamil; this was not felt to be significant since pilot studies revealed no obvious effect on motility. The dependence of the drug effects on extended incubation suggests that only capacitated spermatozoa can respond. 


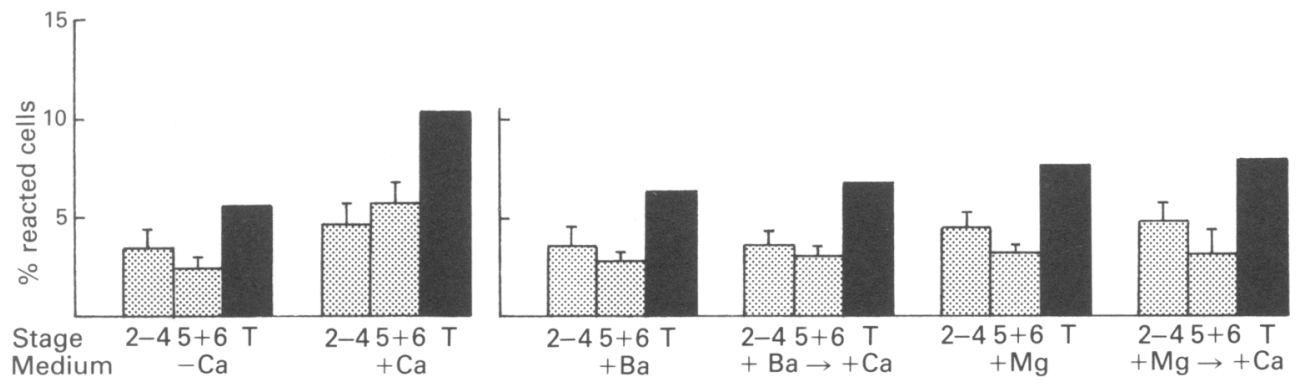

Fig. 7. AR response in human sperm suspensions incubated for $24 \mathrm{~h}$ in calcium-deficient medium $(-\mathrm{Ca})$, media containing $1.80 \mathrm{mM}-\mathrm{CaCl}_{2}(+\mathrm{Ca}),-\mathrm{BaCl}_{2}(+\mathrm{Ba})$ and $-\mathrm{MgCl}_{2}$ $(+\mathrm{Mg})$, and $+\mathrm{Ba}$ and $+\mathrm{Mg}$ media with suspensions receiving $1.80 \mathrm{mM}-\mathrm{CaCl}_{2}$ for the final $15 \mathrm{~min}(+\mathrm{Ba} \rightarrow+\mathrm{Ca},+\mathrm{Mg} \rightarrow+\mathrm{Ca})$. The stippled bars represent the proportion of cells at intermediate Stages $2-4$ and reacted Stages $5+6$. The solid bars (T) represent the total mean reacted cells. Values are mean $\% \pm$ s.e.m. $(n=5)$.

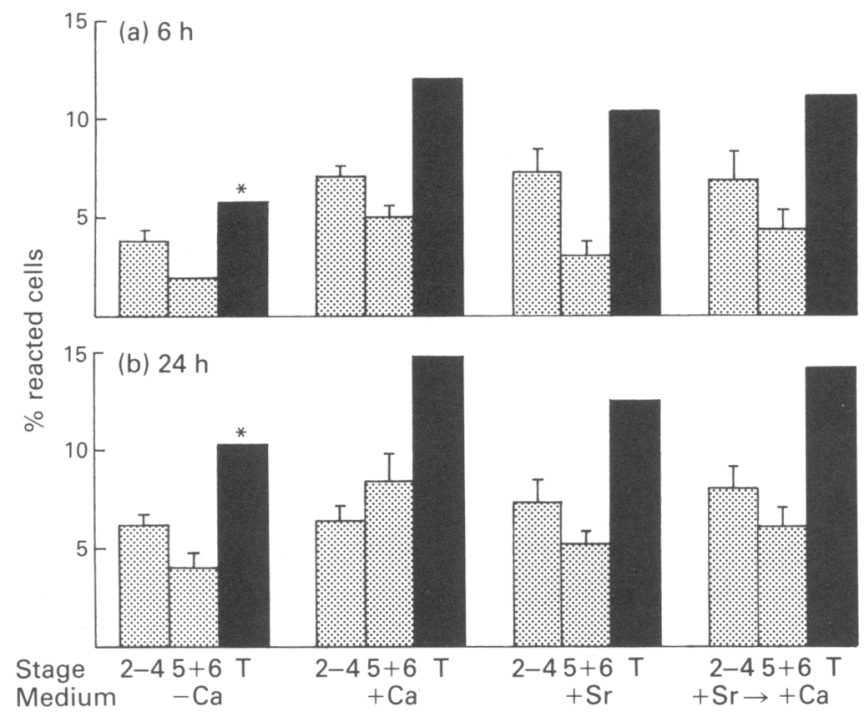

Fig. 8. AR response in human sperm suspensions incubated for (a) $6 \mathrm{~h}$ and (b) $24 \mathrm{~h}$ in calciumdeficient medium ( $-\mathrm{Ca}$ ), calcium-containing medium $\left(+\mathrm{Ca} ; 1.80 \mathrm{~mm}-\mathrm{CaCl}_{2}\right)$, strontiumcontaining medium $\left(+\mathrm{Sr} ; 1.80 \mathrm{mM}-\mathrm{SrCl}_{2}\right)$ and strontium-containing medium, centrifuged and resuspended in $+\mathrm{Ca}$ medium for final $15 \mathrm{~min}(+\mathrm{Sr} \rightarrow+\mathrm{Ca})$. Values are mean $\% \pm$ s.e.m. $(n=8) .{ }^{*} P<0.05$ compared with + Ca controls.

\section{Series VII: can $\mathrm{Ba}^{2+}$ and $\mathrm{Mg}^{2+}$ substitute for $\mathrm{Ca}^{2+}$ during capacitation and the $\mathrm{AR}$ ?}

The total mean proportion of sperm cells which had initiated (Stages 2-4) or completed (Stages $5 \& 6)$ the AR after $24-\mathrm{h}$ incubation was lower in all 5 treatment groups $(-\mathrm{Ca}, 5 \cdot 6 \% ;+\mathrm{Ba}, 6.4 \%$; $+\mathrm{Ba} \rightarrow+\mathrm{Ca}, 6 \cdot 8 \% ;+\mathrm{Mg}, 7 \cdot 7 \% ;+\mathrm{Mg} \rightarrow+\mathrm{Ca}, 8.0 \%$ ) compared with the control group, $+\mathrm{Ca}$ $(10 \cdot 2 \%)$. Again, relatively few cells in - Ca medium were at Stages 5 and 6 and a similar pattern was observed in all $+\mathrm{Ba}$ and $+\mathrm{Mg}$ samples. This contrasts with the $+\mathrm{Ca}$ group in which the 


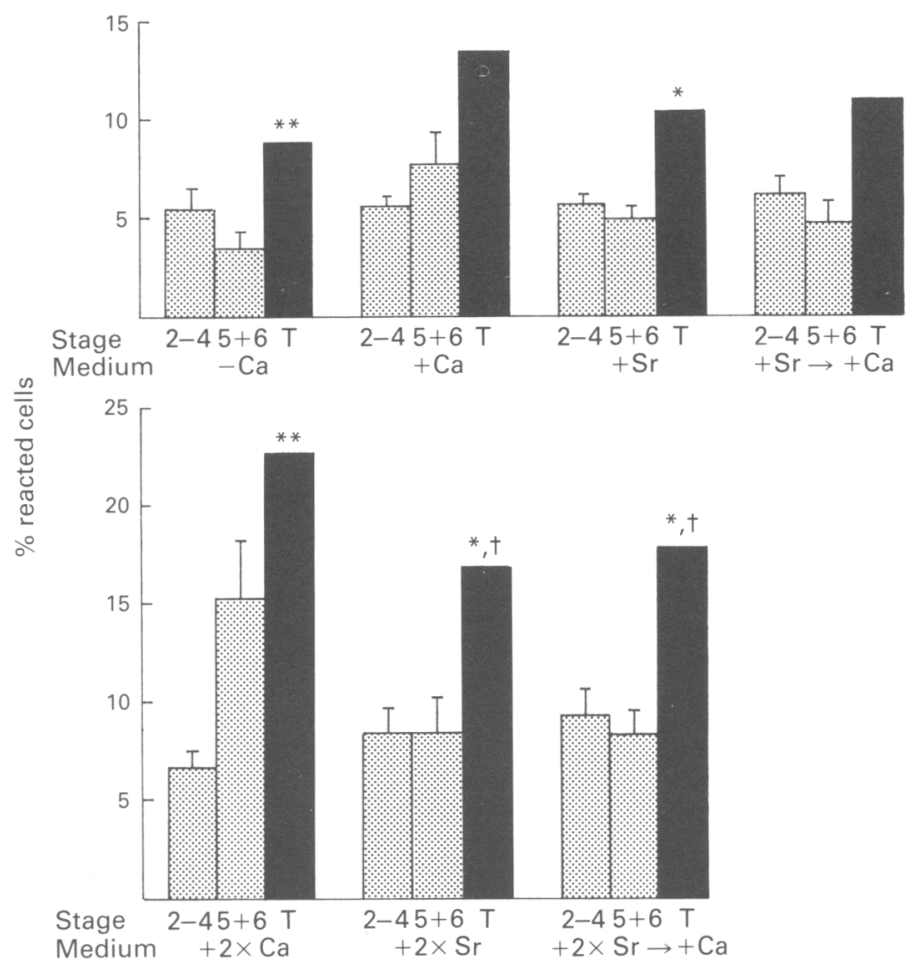

Fig. 9. AR response in human sperm suspensions incubated for $24 \mathrm{~h}$ in the following media: calcium-deficient $(-\mathrm{Ca})$, calcium-containing $(+\mathrm{Ca})$, strontium-containing $(+\mathrm{Sr})$, elevated calcium $\left(+2 \times \mathrm{Ca} ; 3.60 \mathrm{~mm}-\mathrm{CaCl}_{2}\right)$ and elevated strontium $\left(+2 \times \mathrm{Sr} ; 3.60 \mathrm{~mm}-\mathrm{SrCl}_{2}\right)$ Aliquants of the strontium-incubated suspension were centrifuged and resuspended in $+\mathrm{Ca}$ medium $(+\mathrm{Sr} \rightarrow+\mathrm{Ca} ;+2 \times \mathrm{Sr} \rightarrow+\mathrm{Ca})$. Values are mean $\% \pm$ s.e.m. $(n=6-9)$. ${ }^{*} P<0.05$, ${ }^{* *} P<0.01$ compared with + Ca controls; $\uparrow P<0.05$ compared with $+2 \times$ Ca suspensions.

majority of cells were fully reacted (Fig. 7). Motility was maintained at $\geq 95 \%$ in all groups except those with $+\mathrm{Mg}$, in which a slightly lower level of $\sim 90 \%$ was observed. From these results we conclude that milimolar concentrations of barium and magnesium cannot substitute for calcium in supporting or fully preparing for the AR.

\section{Series VIII: can $\mathrm{Sr}^{2+}$ substitute for $\mathrm{Ca}^{2+}$ during capacitation and the $\mathrm{AR}$ ?}

At 6 and $24 \mathrm{~h}$, the mean proportion of cells at Stages $2-6$ was significantly lower $(P<0.05)$ in the - Ca group $(5 \cdot 8 \%$ and $10 \cdot 4 \%$, respectively) than in the $+\mathrm{Ca}$ controls $(12 \cdot 1 \%$ and $14 \cdot 7 \%$, respectively). Although the equivalent figures for the $+\mathrm{Sr}$ group were slightly lower $(6 \mathrm{~h}, 9.6 \%$; $24 \mathrm{~h}, 12.5 \%$ ) than the controls, the difference was not significant (Fig. 8). Likewise, the values for $+\mathrm{Sr} \rightarrow+\mathrm{Ca}(6 \mathrm{~h}, 11 \cdot 1 \% ; 24 \mathrm{~h}, 14 \cdot 1 \%)$ did not differ significantly from the controls. At both time points the total response in $+\mathrm{Sr}$ and $+\mathrm{Sr} \rightarrow+\mathrm{Ca}$ suspensions was higher than that observed in $-\mathrm{Ca}$; this difference was statistically significant $(P<0.05)$ for $+\mathrm{Sr} \rightarrow+\mathrm{Ca}$ at $6 \mathrm{~h}$ and nearly so at $24 \mathrm{~h}\left(\chi^{2}=3 \cdot 82\right)$. The majority of Sr-treated cells at both times were at Stages $2-4$, in a pattern similar to that seen in $-\mathrm{Ca}$; in contrast, at $24 \mathrm{~h}$ the majority of cells in $+\mathrm{Ca}$ were fully reacted. Motility was maintained at $\geq 95 \%$ in all groups. Therefore, while it would appear that $\mathrm{Sr}^{2+}$ promotes a greater response than that observed in the absence of $\mathrm{Ca}^{2+}$, it does not support completion of the reaction as successfully as does $\mathrm{Ca}^{2+}$. 


\section{Series IX: does elevated $\mathrm{Sr}^{2+}$ increase the $\mathrm{AR}$ in a manner similar to elevated $\mathrm{Ca}^{2+}$ ?}

The effect on the AR of incubating suspensions in medium containing increased $\mathrm{Sr}^{2+}(3.60 \mathrm{mM}$; $+2 \times \mathrm{Sr})$, with and without the addition of $\mathrm{Ca}^{2+}(+2 \times \mathrm{Sr},+2 \times \mathrm{Sr} \rightarrow+\mathrm{Ca})$ was compared with that obtained in media containing different amounts of $\mathrm{Ca}^{2+}$ or $\mathrm{Sr}^{2+}:-\mathrm{Ca},+\mathrm{Ca},+\mathrm{Sr},+\mathrm{Sr} \rightarrow+$ $\mathrm{Ca},+2 \times \mathrm{Ca}$ (Fig. 9). When all responses were compared with $+\mathrm{Ca}$ suspensions (mean of $13.4 \%$ cells at Stages $2-6)$, a significantly lower $(P<0.01)$ AR response was observed in - Ca medium $(8.8 \%)$. In the $+\mathrm{Sr}$ suspensions, $10 \cdot 4 \%$ of cells had responded; while this value was significantly lower $(P<0.05)$ than the controls, the similar but very slightly higher response in $+\mathrm{Sr} \rightarrow+\mathrm{Ca}$ of $10 \cdot 9 \%$ was not significantly different.

The AR in the presence of elevated concentrations of divalent cation was significantly higher compared with controls $(13.4 \%)$ : $+2 \times \mathrm{Ca}, 22.6 \%(P<0.01) ;+2 \times \mathrm{Sr}, 16.8 \%(P<0.05)$; $+2 \times \mathrm{Sr} \rightarrow+\mathrm{Ca}, 17.8 \%(P<0.05)$. At the same time, the response to $+2 \times \mathrm{Sr}$ was significantly lower $(P<0.05)$ when compared with the $+2 \times$ Ca response. In 5 suspensions (data not presented in Fig. 9) we also evaluated the conditions $+2 \times \mathrm{Sr} \rightarrow+2 \times \mathrm{Ca}$; with the addition of elevated $\mathrm{Ca}^{2+}$, the corresponding AR figure was $19 \cdot 2 \%$, with about half the cells fully reacted. Thus, while elevated $\mathrm{Sr}^{2+}$ evokes a greater response than $+\mathrm{Ca}$, it is less effective than elevated $\mathrm{Ca}^{2+}$. Moreover, $\sim 70 \%$ of responding cells in $+2 \times$ Ca were fully reacted compared with only $47-50 \%$ in the two $+2 \times \mathrm{Sr}$-treated groups. Therefore, even elevated $\mathrm{Sr}^{2+}$ concentrations are less able to support the complete reaction. Again, motility was maintained at $\geq 95 \%$ in all groups.

\section{Discussion}

Consistent with observations made in numerous other species, invertebrate and vertebrate, our results indicate that the presence of extracellular $\mathrm{Ca}^{2+}$ permits a significantly higher proportion of human spermatozoa to undergo the spontaneous $\mathrm{AR}$ than is observed in $\mathrm{Ca}^{2+}$-deficient conditions. Furthermore, $\mathrm{Ca}^{2+}$ also appears to be required during capacitation, with effective concentrations being in the millimolar range. Extended preincubation in micromolar amounts of $\mathrm{Ca}^{2+}$ does not prepare human spermatozoa to respond rapidly to millimolar $\mathrm{Ca}^{2+}$ and undergo the AR. In having a $\mathrm{Ca}^{2+}$ requirement during capacitation, human spermatozoa are similar to mouse spermatozoa, but the concentrations required for the human cells $(\geq 1.80 \mathrm{~mm})$ are much higher than comparable ones for the mouse $(90 \mu \mathrm{M}$; Fraser, 1987b). The greatest human sperm AR response was seen when samples were incubated continuously in elevated $\mathrm{Ca}^{2+}(3.60 \mathrm{~mm})$. The fact that differences between 1.80 and $3.60 \mathrm{mM}-\mathrm{Ca}^{2+}$-incubated suspensions were detectable at $6 \mathrm{~h}$ and significantly higher in $3.60 \mathrm{~mm}$ at $24 \mathrm{~h}$ suggests that these conditions may both accelerate/promote capacitation and trigger the AR in a greater proportion of spermatozoa. This would be consistent with results obtained for the mouse in which elevated $\mathrm{Ca}^{2+}$ concentrations $(3.60 \mathrm{mM})$ precociously stimulated the AR and in-vitro fertilizing ability (Fraser, 1987b). Whether elevated $\mathrm{Ca}^{2+}$ would promote enhanced functional ability in human spermatozoa cannot be predicted. Extended incubation in $\geq 3.60 \mathrm{mM}-\mathrm{Ca}^{2+}$ irreversibly damaged mouse sperm fertilizing ability and even a short incubation in $7.20 \mathrm{mM}-\mathrm{Ca}^{2+}$ was deleterious; these effects appeared to be associated with qualitative effects on motility (Fraser, 1987b).

Our data also provide evidence that while the divalent cations $\mathrm{Ba}^{2+}$ and $\mathrm{Mg}^{2+}$ cannot effectively substitute for $\mathrm{Ca}^{2+}, \mathrm{Sr}^{2+}$ can do so: the mean total of responding cells was not significantly different from that obtained in $\mathrm{Ca}^{2+}$-containing medium (Fig. 8). However, a consistent difference in the distribution of cells between intermediate and completed stages of the AR was observed, with the majority of cells in $\mathrm{Ca}^{2+}$ being completely reacted and the majority in $\mathrm{Sr}^{2+}$ at intermediate stages (Fig. 8,9). This latter pattern is also seen in $\mathrm{Ca}^{2+}$-deficient and low $\mathrm{Ca}^{2+}$ conditions (Figs $1-3$ and 7-9) and in $\mathrm{Ba}^{2+}$ or $\mathrm{Mg}^{2+}$ (Fig. 7), suggesting that they are less able to promote the complete AR. Motility was maintained at $\geq 90 \%$ for $24 \mathrm{~h}$. The total of reacting and reacted cells in $\mathrm{Ca}^{2+}$. deficient medium increased slightly from $6 \mathrm{~h}$ to $24 \mathrm{~h}$. It is likely that this increase is due in part to 
some cells dying during incubation and losing the acrosome. There is also the possibility that during the swim-up preparation the cells bound sufficient $\mathrm{Ca}^{2+}$ from seminal plasma to promote the early stages of the AR. Certainly completion of the AR in such spermatozoa would appear to require millimolar concentrations of $\mathrm{Ca}^{2+}$.

Current evidence (reviewed by Fraser, 1987a) indicates that capacitation involves a rise in the intracellular $\mathrm{Ca}^{2+}$ concentrations (e.g. White \& Aitken, 1989) which leads ultimately to triggering of the AR. Divalent cation ionophores, in the presence of extracellular $\mathrm{Ca}^{2+}$, increase the uptake of $\mathrm{Ca}^{2+}$ into spermatozoa (Babcock et al., 1976; Peterson \& Freund, 1976) and can effectively bypass the temporal requirements of capacitation, resulting in precocious AR (e.g. guinea-pig and hamster: Talbot et al., 1976; boar: Peterson et al., 1978; mouse: Fraser, 1982; ram: Shams-Borhan \& Harrison, 1981; human: Jamil \& White, 1981). Using the $\mathrm{Ca}^{2+}$ ionophore ionomycin we have confirmed that ionophores can eliminate the need for extended incubation of human spermatozoa normally required to obtain the characteristic incidence of $\sim 15 \%$ spontaneous AR (Stock \& Fraser, 1987). A 15-min exposure to ionomycin at $0 \mathrm{~h}$ was essentially as effective in inducing the AR as a similar exposure following a 6-h drug-free preincubation. In this, our results contrast markedly with those of Byrd et al. (1989), in which the greatest response to ionophore was only observed in suspensions preincubated for $6 \mathrm{~h}$ before treatment. Lee et al. (1987) have also reported that ionophore treatment of fresh suspensions failed to stimulate the AR. The reason for these discrepancies is unclear. The media differed, being Earle's in our study and BWW in the others, but Cross et al. (1986) and Aitken et al. (1984) have provided evidence of rapid responses to ionophore in BWW medium. Indeed, the majority of similar studies have observed rapid responses of uncapacitated sperm suspensions to ionophore, both in terms of AR (e.g. Shams-Borhan \& Harrison, 1981; Fraser, 1982; Cross et al., 1986) and increased fertilizing ability (e.g. Fraser, 1982; Aitken et al., 1984).

In agreement with Byrd et al. (1989) we observed a concentration-dependent response to ionomycin over the range examined $(3-30 \mu \mathrm{M})$. The mean maximum response in the $30 \mu \mathrm{M}$-treated group was approximately $60 \%$, with a high proportion $(\sim 50 \%)$ of cells at intermediate stages probably reflecting the short incubation after ionophore addition; a longer incubation would have allowed completion of the AR. While it is possible that a longer exposure to ionophore would have increased the proportion of reacted cells, this level of response is similar to that in other studies of human spermatozoa in the presence of ionophore, commonly A23187 but occasionally ionomycin. The maximum response noted, in some instances after several hours of incubation in ionophore, has consistently fallen within the range of $\sim 40-70 \%$ reacting cells rather than approaching $100 \%$ (Russell et al., 1979; Jamil \& White, 1981; Aitken et al., 1984; Tesařik, 1985; Cross et al., 1986; Lee et al., 1987; Thomas \& Meizel, 1988; Byrd et al., 1989; Mortimer \& Camenzind, 1989). This suggests that some of the cells, even in selected and highly motile suspensions, are unable to respond to this exogenous stimulus and therefore may be inherently defective. The presence of a smaller proportion of reacting cells could be associated with basic cellular dysfunction. Aitken et al. (1984) have presented evidence that while A23187 treatment of sperm suspensions from men of proven fertility was associated with an increase in successful penetration of zona-free hamster eggs, similar treatment of samples from oligozoospermic men failed to alter markedly the poor penetration pattern observed. These same workers have suggested recently that at least one type of dysfunction in such suspensions is an excessive production of reactive oxygen species (Aitken \& Clarkson, 1987).

We failed to observe any correlation between the concentration of extracellular $\mathrm{Ca}^{2+}$ and maintenance of sperm motility. Motility was maintained equally well for $24 \mathrm{~h}$ whether the medium was $\mathrm{Ca}^{2+}$-deficient ( $\sim 15 \mu \mathrm{M}$-free $\mathrm{Ca}^{2+}$; Fraser, 1987b) or contained $\mathrm{Ca}^{2+}$ at 1.80-3.60 mm. There have been numerous conflicting reports regarding $\mathrm{Ca}^{2+}$ and human sperm motility (see Hong et al., 1984). In suspensions which have been removed from seminal plasma and then incubated in prepared media, the $\mathrm{Ca}^{2+}$ concentration is more likely to affect qualitative features of motility which we did not evaluate, particularly hyperactivated motility (e.g. in mouse: Fraser, 1982; Cooper, 
1984). A preliminary study has suggested that a correlation exists between the extracellular $\mathrm{Ca}^{2+}$ concentration and the proportion of human spermatozoa exhibiting hyperactivated motility (Robertson \& Mortimer, 1988). Our observation that exposure to a high concentration of ionophore ( $30 \mu \mathrm{M}$-ionomycin) resulted in fairly rapid loss of motility is consistent with similar effects noted in other studies using ionophores (e.g. Shams-Borhan \& Harrison, 1981; Fraser, 1982; Aitken et al., 1984; Tesarík, 1985; Thomas \& Meizel, 1988). This response is due to ionophore-related effects on mitochondrial $\mathrm{Ca}^{2+}$ concentrations (Reed \& Lardy, 1972). There are ways of manipulating treated suspensions to maintain motility (Shams-Borhan \& Harrison, 1981; Fraser, 1982; Thomas \& Meizel, 1988), particularly important for demonstrating fertilizing ability. However, we terminated all experiments $15 \mathrm{~min}$ after introduction of ionomycin and hence made no attempt to maintain or re-establish full motility.

Using ultrastructural characteristics as the basis for assessment, we have consistently observed features of the human AR which differ from the generally accepted pattern of the mammalian sperm AR. In particular, the intermediate AR stages in human cells appear to involve the formation of intra-acrosomal vesicles, primarily derived from the outer acrosomal membrane (Nagae et al., 1986; Stock \& Fraser, 1987), rather than vesicles formed from fusion between plasma and outer acrosomal membranes (see Bedford, 1983). In contrast, however, another recent study (Yudin et al., 1988) has reported that the human AR conforms to the general mammalian pattern. Clearly these discrepancies need to be addressed. The possibility that human spermatozoa considered to be at intermediate stages of the reaction might simply be degenerating has been considered. The consistency with which these stages have been observed under a variety of conditions in which very high levels of motility are maintained, an indication that cells are not moribund, would appear to negate this (e.g. Stock \& Fraser, 1987; Stock et al., 1988, 1989). Furthermore, the observation of increased numbers of cells at intermediate stages in the present ionomycin experiments, in which recently prepared suspensions were treated for $15 \mathrm{~min}$ and fixed while motility was high (particularly in 3 and $10 \mu \mathrm{M}$-ionomycin treated groups), would argue strongly against an association with degenerative changes.

Our data indicate that human sperm capacitation and the spontaneous AR require the presence of millimolar concentrations of extracellular $\mathrm{Ca}^{2+}$. The fact that a brief exposure to ionophore induces the AR suggests that at least some of the $\mathrm{Ca}^{2+}$ is internalized before the reaction and Irvine $\&$ Aitken (1986) have demonstrated that ionomycin treatment of human spermatozoa results in a rise in intracellular $\mathrm{Ca}^{2+}$. Thomas \& Meizel (1988) have recently presented evidence that a transient increase in intracellular free $\mathrm{Ca}^{2+}$ occurs concomitantly with the AR. Because both this rise and the $\mathrm{AR}$ can be blocked by addition of chelators or $\mathrm{La}^{3+}, \mathrm{a} \mathrm{Ca}^{2+}$-antagonist, these authors also conclude that the AR requires an influx of extracellular $\mathrm{Ca}^{2+}$. However, the mechanisms controlling such an influx have yet to be identified. In sea urchin spermatozoa, the ability of drugs which antagonize voltage-sensitive calcium channels in somatic cells (Triggle \& Janis, 1987) to block a $\mathrm{Ca}^{2+}$-induced AR suggests that these channels play an important role in $\mathrm{Ca}^{2+}$ influx (Schackmann et al., 1978; Kazazoglou et al., 1985). The evidence from mammalian spermatozoa is more equivocal since treatment of spermatozoa with drugs (e.g. verapamil, D600 and various dihydropyridines) usually regarded as antagonists of such calcium channels has generally had no effect or has enhanced the AR response (e.g. Singh et al., 1980; Roldan et al., 1986). However, recent studies have provided support for the existence of similar channels in ram (Babcock \& Pfeiffer, 1987) and mouse spermatozoa (Fraser \& McIntyre, 1989). We have demonstrated that verapamil and the dihydropyridine nifedipine do not block capacitation per se (Fraser \& McIntyre, 1989) but can block a $\mathrm{Ca}^{2+}$-stimulated AR in capacitated mouse sperm cells. The blocking of the AR was only observed when spermatozoa were capacitated in low $\mathrm{Ca}^{2}+(90 \mu \mathrm{M})$ medium. While not supporting the AR, these conditions do support capacitation since introduction of millimolar $\mathrm{Ca}^{2+}$ results in rapid triggering of the AR and fertilizing ability (Fraser, 1987b); however, the introduction of calcium channel antagonists before the millimolar $\mathrm{Ca}^{2+}$ significantly inhibited the $A R$ response. In contrast, addition of these same drugs to suspensions capacitated in millimolar 
$\mathrm{Ca}^{2+}$ resulted in a significantly increased AR response. This suggested that these cells were in an altered state, possibly due to accumulation of intracellular $\mathrm{Ca}^{2+}$ to critical threshold levels, such that these same drugs, usually observed to have antagonistic effects on calcium channels, had an agonistic effect. Studies in somatic cells have demonstrated that 'antagonists' can have agonistic effects under appropriate conditions (Scott \& Dolphin, 1987).

Given that human spermatozoa appear to require prolonged incubation in millimolar $\mathrm{Ca}^{2+}$, the capacitation phase presumably requires or allows the intracellular $\mathrm{Ca}^{2+}$ to rise to a level approximating such an altered state. If drugs such as verapamil did not affect calcium channels during capacitation per se in human spermatozoa, as is the case for their mouse counterparts, then one would predict that verapamil could have an agonistic effect on these channels in capacitated cells, leading to an influx of $\mathrm{Ca}^{2+}$ and the AR. Both our observation of a concentration- and timedependent increase in the proportion of reacted cells and the enhanced responses observed in studies of other mammalian spermatozoa cited above are consistent with this hypothesis. The fact that at a given concentration the response was highest in suspensions incubated for $24 \mathrm{~h}$ argues strongly that the AR was elicited in capacitated spermatozoa. This pattern of response differs markedly from the ionophore-induced AR, for which maximal responses could be evoked at the very start of sperm incubation (see Figs $5 \& 6$ ). Also consistent with our hypothesis is the observation of Irvine \& Aitken (1986) that neither verapamil nor diltiazem affected either the resting level of intracellular $\mathrm{Ca}^{2+}$ or the passage of $\mathrm{Ca}^{2+}$ into uncapacitated human spermatozoa when the extracellular $\mathrm{Ca}^{2+}$ concentration was increased. We therefore propose that calcium channels may exist in human spermatozoa. While not controlling $\mathrm{Ca}^{2+}$ influx during capacitation, they could function at the end of capacitation with agonisticinteractions between channels and oocyte-associated molecules resulting in a $\mathrm{Ca}^{2+}$ influx and triggering of the AR.

This study and many others have provided evidence that $\mathrm{Ca}^{2+}$ can support capacitation and the $\mathrm{AR}$, and this would be the most abundant divalent cation in vivo. Of the various other divalent cations assessed, only $\mathrm{Sr}^{2+}$ supported responses similar to $\mathrm{Ca}^{2+}$ (Figs 7, 8 \& 9). Although Mortimer (1986) and Mortimer et al. (1986) suggested that $\mathrm{Sr}^{2+}$-incubated spermatozoa were able to undergo capacitation but not the AR, our data do not support this proposal and Mortimer et al. (1988) have reached the same conclusion since they were unable to detect any significant differences in $\mathrm{AR}$ in the presence of $2.4 \mathrm{~mm}-\mathrm{Sr}^{2+}$ and $2.4 \mathrm{mM}-\mathrm{Ca}^{2+}$. They did observe, however, that sperm penetration of zona-free hamster eggs was considerably lower in $\mathrm{Sr}^{2+}$ than $\mathrm{Ca}^{2+}$. In an earlier study, Yanagimachi (1978) reported that, while $1.71{\mathrm{mM}-\mathrm{Sr}^{2+}}^{2}$ supported little penetration of human spermatozoa into similar hamster eggs, $3.0 \mathrm{mM}-\mathrm{Sr}^{2+}$ was nearly as effective as $1.71 \mathrm{~mm}$ $\mathrm{Ca}^{2+}$ plus $1 \cdot 19 \mathrm{~mm}-\mathrm{Mg}^{2+}$. Whether these discrepancies possibly reflect differences in $\mathrm{the}^{2+}$ concentration or the presence of EGTA in the Mortimer et al. (1988) study is uncertain. Our results indicate that the proportion of responding cells is certainly higher in $3.60 \mathrm{~mm}$ - than in $1.80 \mathrm{~mm}$ $\mathrm{Sr}^{2+}$, both for fully reacted cells as well as all reacting cells. Higher fusion rates in elevated $\mathrm{Sr}^{2+}$ would therefore be consistent with earlier reports that only acrosome-reacted spermatozoa can fuse with the egg plasma membrane (Yanagimachi, 1981).

Additionally, Mortimer et al. (1988) examined the ability of suspensions incubated in either $\mathrm{Sr}^{2+}$ - or $\mathrm{Ca}^{2+}$-containing medium to bind to salt-stored human zonae pellucidae. Noting that approximately twice as many motile cells bound in the presence of $\mathrm{Ca}^{2+}$ as in $\mathrm{Sr}^{2+}$, they concluded that sperm-zona interactions in the human are less effectively supported by $\mathrm{Sr}^{2+}$. It is therefore suggestive that we observed fewer spermatozoa that were fully acrosome-reacted in $\mathrm{Sr}^{2+}$-containing medium. Perhaps a completed $\mathrm{AR}$ is a prerequisite for zona binding in the human. This apparent inability of $\mathrm{Sr}^{2+}$ to substitute fully for $\mathrm{Ca}^{2+}$ in zona binding is in direct contrast to observations in the mouse: mouse spermatozoa were able to interact with the zona and achieve normal penetration in $\mathrm{Sr}^{2+}$-containing medium as evidenced by the presence of numerous spermatozoa in the perivitelline space (Fraser, 1987c). Fusion with zona-intact eggs was minimal because of $\mathrm{Sr}^{2+}$-induced egg activation, but when zona-free eggs were used essentially all were penetrated and exhibited a high incidence of polyspermy. The report by Heffner et al. (1980) that $\mathrm{Sr}^{2+}$ did not 
support sperm-zona binding in the mouse would appear to reflect the use of a minimal, possibly non-physiological, medium, containing only Tris- $\mathrm{HCl}$ and $\mathrm{NaCl}$ in addition to $\mathrm{Sr}^{2+}$.

The ability of $\mathrm{Sr}^{2+}$ to replace $\mathrm{Ca}^{2+}$ in the changes undergone by spermatozoa which are required for fertilization would therefore appear to be species-specific. $\mathrm{Sr}^{2+}$ can completely substitute for $\mathrm{Ca}^{2+}$ in mouse spermatozoa, supporting capacitation, the AR, sperm-zona binding and gamete fusion. In human spermatozoa $\mathrm{Sr}^{2+}$ can replace $\mathrm{Ca}^{2+}$ during capacitation and initiation of the AR, but it is less effective in supporting completion of the AR. This may explain, in part, the apparent inability of $\mathrm{Sr}^{2+}$ to substitute for $\mathrm{Ca}^{2+}$ during zona binding and gamete fusion.

In conclusion, our results indicate that the continuous presence of millimolar $\mathrm{Ca}^{2+}$ is required to ensure that a maximal spontaneous $\mathrm{AR}$ is obtained, suggesting that $\mathrm{Ca}^{2+}$ is needed during both capacitation and the AR. In either the absence of added $\mathrm{Ca}^{2+}$ or in low $\mathrm{Ca}^{2+}$, a significantly lower proportion of spermatozoa initiate, and few complete, the AR compared with their counterparts incubated in $\geq 1.80 \mathrm{mM}-\mathrm{Ca}^{2+}$. They are unable to respond rapidly to millimolar $\mathrm{Ca}^{2+}$, even after $24 \mathrm{~h}$ incubation. Of the other divalent cations assessed, $\mathrm{Sr}^{2+}$ was able to substitute for $\mathrm{Ca}^{2+}$ although it proved less effective than $\mathrm{Ca}^{2+}$ in promoting completion of the AR. That some of the $\mathrm{Ca}^{2+}$ must enter the cell is indicated by the ability of the ionophore ionomycin to remove the timedependent features of the spontaneous response and induce an immediate AR. Finally, calcium channels, capable of modulating $\mathrm{Ca}^{2+}$ influx prior to the AR, may exist in human spermatozoa.

We thank Dr K. Lindsay and Mr D. K. Edmonds for assistance and advice during this study and A. Osborne for artwork. This work was supported by a grant to L.R.F. from Birthright.

\section{References}

Aitken, R.J. \& Clarkson, J.S. (1987) Cellular basis of defective sperm function and its association with the genesis of reactive oxygen species by human spermatozoa. J. Reprod. Fert. 81, 459-469.

Aitken, R.J., Ross, A., Hargreave, T., Richardson, D. \& Best, F. (1984) Analysis of human sperm function following exposure to the ionophore A23187. $J$. Androl. 5, 321-329.

Babcock, D.F. \& Pfeiffer, D.R. (1987) Independent elevation of cytosolic $\left[\mathrm{Ca}^{2+}\right]$ and $\mathrm{pH}$ of mammalian sperm by voltage-dependent and $\mathrm{pH}$-dependent mechanisms. J. biol. Chem. 262, 15041-15047.

Babcock, D.F., First, N.L. \& Lardy, H.A. (1976) Action of ionophore A23187 at the cellular level. Separation of the effects at the plasma and mitochondrial membranes. J. biol. Chem. 251, 3881-3886.

Bedford, J.M. (1983) Significance of the need for sperm capacitation before fertilization in eutherian mammals. Biol. Reprod. 28, 108-120.

Byrd, W., Tsu, J. \& Wolf, D.P. (1989) Kinetics of spontaneous and induced acrosomal loss in human sperm incubated under capacitating and noncapacitating conditions. Gamete Res. 22, 109-122.

Cooper, T.G. (1984) The onset and maintenance of hyperactivated motility of spermatozoa from the mouse. Gamete Res. 9, 55-74.

Cross, N.L., Morales, P., Overstreet, J.W. \& Hanson, F.W. (1986) Two simple methods for detecting acrosome reacted human sperm. Gamete Res. 15, 213-226.

Fraser, L.R. (1982) $\mathrm{Ca}^{2+}$ is required for mouse sperm capacitation and fertilization in vitro. J. Androl. 3, $412-419$.
Fraser, L.R. (1987a) Extracellular calcium and fertilization-related events. In The Role of Calcium in Biological Systems, Vol. IV, pp. 163-190. Ed. L. J. Anghileri. CRC Press, Boca Raton.

Fraser, L.R. (1987b) Minimum and maximum extracellu$\operatorname{lar} \mathrm{Ca}^{2+}$ requirements during mouse sperm capacitation and fertilization in vitro. J. Reprod. Fert. 81, 77-89.

Fraser, L.R. (1987c) Strontium supports capacitation and the acrosome reaction in mouse sperm and rapidly activates mouse eggs. Gamete Res. 18, 363-374.

Fraser, L.R. \& McIntyre, K. (1989) Calcium channel antagonists modulate the acrosome reaction but not capacitation in mouse spermatozoa. J. Reprod. Fert. 86, 223-233.

Heffner, L.J., Saling, P.M. \& Storey, B.T. (1980) Separation of calcium effects on motility and zona binding ability in mouse spermatozoa. J. exp. Zool. 212, 53-59.

Hong, C.Y., Chiang, B.N. \& Turner, P. (1984) Calcium ion is the key regulator of human sperm function. The Lancet ii, 1449-1451.

Irvine, D.S. \& Aitken, R.J. (1986) Measurement of intracellular calcium in human spermatozoa. Gamete Res. $15,57-71$.

Iwamatsu, T. \& Chang, M.C. (1971) Factors involved in the fertilization of mouse eggs in vitro. J. Reprod. Fert. 26, 197-208.

Jamil, K. \& White, I.G. (1981) Induction of acrosomal reaction in sperm with ionophore A23187 and calcium. Archs Androl. 7, 283-292.

Kazazoglou, T., Schackmann, R.W., Fosset, M. \& Shapiro, B.M. (1985) Calcium channel antagonists inhibit the 
acrosome reaction and bind to plasma membranes of sea urchin sperm. Proc. natn. Acad. Sci. USA 82, 1462-1464.

Lee, M.A., Trucco, G.S., Bechtol, K.S., Wummer, N., Kopf, G.S., Blasco, L. \& Storey, B.T. (1987) Capacitation and acrosome reactions in human spermatozoa monitored by a chlortetracycline fluorescence assay. Fert. Steril. 48, 649-658.

Loeb, J. (1915) On the nature of the conditions which determine or prevent the entrance of the spermatozoa into the egg. Am. Nat. 49, 257-285.

Mortimer, D. (1986) Comparison of the fertilizing ability of human spermatozoa preincubated in calcium + and strontium-containing media. J. exp. Zool. 237, 21-24.

Mortimer D. \& Camenzind, D. (1989) The role of follicular fluid in inducing the acrosome reaction of human spermatozoa incubated in vitro. Human Reprod. 4, 169-174.

Mortimer, D., Curtis, E.F. \& Dravland, J.E. (1986) The use of strontium-substituted media for capacitating human spermatozoa: an improved sperm preparation method for the zona-free hamster egg penetration test. Fert. Steril. 46, 97-103.

Mortimer, D., Chorney, M.J., Curtis, E.F. \& Trounson, A.O. (1988) Calcium dependence of human sperm fertilizing ability. J. exp. Zool. 246, 194-201.

Nagae, T., Yanagimachi, R., Srivastava, P.N. \& Yanagimachi, H. (1986) Acrosome reaction in human spermatozoa. Fert. Steril. 45, 701-707.

Peterson, R.N. \& Freund, M. (1976) Relationship between motility and the transport and binding of divalent cations to the plasma membrane of human spermatozoa. Fert. Steril. 27, 1301-1307.

Peterson, R.N., Russell, I., Bundman, D. \& Freund, M. (1978) Presence of micro filaments and tubular structures in boar spermatozoa after chemically inducing the acrosome reaction. Biol. Reprod. 19, 459-466.

Reed, P.N. \& Lardy, H.A. (1972) A23187: A divalent cation ionophore. J. biol. Chem. 247, 6970-6977.

Robertson, L. \& Mortimer, D. (1988) The effect of extracellular free $\mathrm{Ca}^{2+}$ on the development of hyperactivated motility in capacitating human spermatozoa. J. Reprod. Fert., Abstr. Ser. 1, 65, abstr.

Roldan, E.R.S., Shibata, S. \& Yanagimachi, R. (1986) Effect of $\mathrm{Ca}^{2+}$ channel antagonists on the acrosome reaction of guinea pig and golden hamster spermatozoa. Gamete Res. 13, 281-292.

Russell, L., Peterson, R.N. \& Freund, M. (1979) Morphologic characteristics of the chemically induced acrosome reaction in human spermatozoa. Fert. Steril. 32, 87-92.

Ryder, T.A. \& Mackenzie, M.L. (1981) Routine preparation of seminal fluid specimens for transmission electron microscopy. J. clin. Pathol. 34, 1006-1009.

Schackmann, R.W., Eddy, E.M. \& Shapiro, B.M. (1978) The acrosome reaction of Strongylocentrotus purpuratus sperm. Ion requirements and movements. Devl Biol. 65, 483-495.

Scott, R.H. \& Dolphin, A.C. (1987) Activation of a G protein promotes agonist responses to calcium channel ligands. Nature, Lond. 330, 760-762.
Shams-Borhan, G. \& Harrison, R.A.P. (1981) Production, characterization and use of ionophore-induced, calcium-dependent acrosome reaction in ram spermatozoa. Gamete Res. 4, 407-432.

Singh, J.P., Babcock, D.F. \& Lardy, H.A. (1980) Induction of accelerated acrosome reaction in guinea pig sperm. Biol. Reprod. 22, 566-570.

Snedecor, G. \& Cochran, W. (1967) Statistical Methods, 6 th edn. Iowa State University Press, Ames.

Stock, C.E. \& Fraser, L.R. (1987) The acrosome reaction in human sperm from men of proven fertility. Hum. Reprod. 2, 109-119.

Stock, C.E., Bates, R., Lindsay, K.S., Edmonds, D.K. \& Fraser, L.R. (1988) Human oocyte cumulus complexes enhance the human acrosome reaction. $J$. Reprod. Fert., Abstr. Ser. 2, 10, abstr.

Stock, C.E., Bates, R., Lindsay, K.S., Edmonds, D.K. \& Fraser, L.R. (1989) Extended exposure to follicular fluid is required for significant stimulation of the acrosome reaction in human spermatozoa. $J$. Reprod. Fert. 86, 401-411.

Talbot, P., Summers, R.G., Hylander, B., Keough, E.M. \& Franklin, L.E. (1976) The role of calcium in the acrosome reaction: an analysis using ionophore A23187. J. exp. Zool. 198, 383-392.

Tesařík, J. (1985) Comparison of acrosome reactioninducing activities of human cumulus oophorus, follicular fluid and ionophore A23187 in human sperm populations of proven fertilizing ability in vitro. $J$. Reprod. Fert. 74, 383-388.

Thomas, P. \& Meizel, S. (1988) An influx of extracellular calcium is required for initiation of the human sperm acrosome reaction induced by human follicular fluid. Gamete Res. 20, 397-411.

Triggle, D.J. \& Janis, R.A. (1987) Calcium channel ligands. Ann. Rev. Pharmacol. Toxicol. 27, 347-369.

White, D.R. \& Aitken, R.J. (1989) Relationship between calcium, cyclic AMP, ATP and intracellular $\mathrm{pH}$ and the capacity of hamster spermatozoa to express hyperactivated motility. Gamete Res. 22, 163-177.

Yanagimachi, R. (1978) Calcium requirement for sperm-egg fusion in mammals. Biol. Reprod. 19, 949958.

Yanagimachi, R. (1981) Mechanisms of fertilization in mammals. In Fertilization and Embryonic Development in vitro, pp. 81-182. Eds L. Mastroianni \& J. D. Biggers. Plenum Publishing, New York.

Yanagimachi, R. (1982) Requirements of extracellular calcium ions for various stages of fertilization and fertilization-related phenomena in the hamster. Gamete Res. 5, 323-344.

Yanagimachi, R. \& Usui, N. (1974) Calcium dependence of the acrosome reaction and activation of guinea pig spermatozoa. Expl Cell Res. 89, 161-174.

Yudin, A.I., Gottlieb, W. \& Meizel, S. (1988) Ultrastructural studies of the early events of the human sperm acrosome reaction as initiated by human follicular fluid. Gamete Res. 20, 11-24.

Received 9 January 1989 